\title{
Juridical Constraints of Correctional Social Work
}

\author{
Tongat* Ratri Novita Erdianti Nu'man Aunuh \\ Faculty of Law of Muhammadiyah Malang University, \\ Raya Tlogomas Street Number 246, Malang, Indonesia
}

\begin{abstract}
While the institutional-based correction is perceived as ineffective and contributing to negatively-complex effects, the correctional social work decreases the negative effects of inmates fostering in correctional institution. This research focuses of two issues: 1) how far the concept of correctional social work can decrease the negative effects of inmates fostering in institutional-based correction and 2) what are the constraints in applying the concept of correctional social work in the Act Number 12 Year 1995 towards the inmates fostering in Indonesia. Through a normative study, a conclusion is derived that the regulation of inmates fostering - neither in correctional act nor in government regulation pertaining to inmates fostering - does not provide the possibility of the constitutional social work application. The inmates fostering based on the existing regulation is still focused on the internal model of the institution. An analysis on various exising regulations showed that there are lots of constraints regarding the application of the concept of correctional social work, mainly on the juridical aspect. One of the examples is the absence of the regulations of the constitutional social work.
\end{abstract}

Keywords: juridical constraints, social work, correction

DOI: $10.7176 / \mathrm{JLPG} / 94-10$

Publication date: February $29^{\text {th }} 2020$

\section{Introduction}

In recent years, correctional problem has always been a prominent issue. A series of riot in correctional institutions became headlines in various media. Wordpress.com reported the "Long List of Correctional Institution Riots in the Country" in the last 15 years before 2016. According to the news, there were 15 riots in correctional institutions followed by social implications throughout the years (https://ferdfound.wordpress.com/2016/04/25/daftar). This indicates that instead of being an ideal place for fostering inmates, the correctional institution seems to be a vile place where many criminal acts are conducted. The problems such as a fire-raising and criminal acts show that the institution needs to be revamped.There are at least two vital issues to be studied. First, the existing concept of institutional-based correction. Can this concept be maintained? Second, the problems occurred in the institution such as criminal acts, drugs trafficking, fire-raising, etc. are suspected not only because of the limitedness of the institution, but also of the regulations. Therefore, all the regulations pertaining to the inmates fostering need to be studied.

Basically, this research aims to figure out the right knowledge to answer and/or to solve a problem (Soetandyo Wignjosoebroto, 2007, thus there is a need of paradigm as a point of view, values, methods, basic principle, or a way of solving problem that embraced by a scientific community in a certain circumstance (Djam'an Satori and Aan Komariah, 2009, jujun S. Suriasumantri, 2009). This study follows the basic assumption built by the paradigm of post-positivism, where values, ethics, and moral choice are in the stream of discussion.

This is a legal reseaarch with several approaches such as statute approach, analytical approach, and philosophical approach (Johnny Ibrahim, 2005). It is not only interpreting the texts, but also capturing the contextual meaning of the texts/language of the regulations (Esmi Warassih, 2006). Moreover, it will explore the values of the law, thus is considered as a philosophical research (Yusriadi, 2009). This research will not only perceive law textually, but also as an idea, purpose, value, moral, and justice that known as ideological, philosophical, and moralistic concept of law (Ronny HanitijoSoemitro, 1989). It will use the secondary data as the main data obtained from a literature review (Soerjono Soekanto and Sri Mamudji, 1995) in form of primary, secondary (Bambang Sunggono, 1997, Soerjono Soekanto and Sri Mamudji, 1995), and tertiary (Soerjono Soekanto dan Sri Mamudji, 1995) legal materials. The secondary data will be systematically presented and then descriptively and analytically analized using the deductive logic (Suteki, 2008). The use of deductive logic in this research is mainly conducted on the selection and using of theory (Sugiyono, 2008).

\section{Theoretical Framework}

Grammatically, the term "correction" refers to a process, procedure, act of socializing oneself into society (Kamus Besar Bahasa Indonesia). It means an effort by a correctional institution to return a rectified inmate to society. In various literature, the discussion on the purpose of punishment in fact indicates various perspective. It means that the conception regarding the purpose of criminalization proposed by the jurists does not show a unity of opinion This is affected by the paradigm of each jurist in perceiving the principle and function of the punishment. One of the jurists proposing the conception of punishment is Alf Ross. In his book "On Guilt, Responsibility and 
Punishment", Ross stated that punishment is essentially a social reaction that (1) occurs where there is violation of a legal rule;(2) is imposed and carried out by authorised persons on behalf of the legal order to which the violated rule belongs; (3) involves suffering or at least other consequences normally considered unpleasant; and (4) expresses disapproval of the violator (Alf Ross, 1975).

Meanwhile, Ted Honderich (2006) gave limitation and concept regarding punishment as an authority’s infliction of a penalty, something involving deprivation or distress, on an offender, someone who has freely and responsibly broken a law or rule, for that offence. This is almost the same as what stated by Alf Ross. The point is, punishment is a suffering inflicted by the authority on a person that is considered as violating the criminal law. Furthermore, in terms of purpose, there are various beliefs regarding the purpose of punishment. According to Matthew Ross Lippman (2010), there are at least five theories of punishment purpose that has their own rationality: retributive theory, utilitarian theory, rehabilitation theory, incapacitation theory, and restorative theory. Nevertheless, due to limited space of discussion, there are only two theories that considered as the most significant theories presented: retributive theory and utilitarian theory.

Theory of revenge considers the conducted criminal act (backward-looking) as the rationality of the punishment, while the theory of purposing tends to consider the effect of the punishment on the perpetrator and society (forward-looking) as the rationality of the punishment (Tongat, 2013). According to the theory of revenge, criminal conviction is justified due to the criminal act. The justification occurred because a person has conducted a criminal act (quia peccatum est) (Muladi and Barda Nawawi Arief, 1998). Thus, a criminal conviction has no other purpose but punishing a person who conducts a criminal act. Meanwhile, according to the theory of purposing, punishment is not simply an act of revenge to the one who conduct a criminal act. It has further purpose. Karl O. Christiansen (Muladi and Barda Nawawi Arief, 1998) stated that the characteristics of punishment are as follows:

a. the purpose of a punishment is prevention

b. prevention is not the final purpose; it is only a means of achieving higher purpose: social welfare;

c. only the violation of law that can be accused upon the perpetrator - for example, due to wilfulnes and neglect - that meet the requirements of punishment

d. a punishment should be determined based on its purpose as a means of preventing crime;

e. A punishment is prospective and can contain the element of denunciation; however, both the denunciation or revenge are not acceptable if they are not helping the crime prevention for social welfare.

\section{The Concept of Correctional Social Work in Reducing the Negative Effect of Inmates Fostering in Institutional-Based Correction}

As explained in the theoretical framework section, correction is essentially an effort to return a person to society (resocialization of convicted person). Meanwhile, social work is an activity conducted by a person to provide service to society with or without reward. The constitulized social work in this research refers to the process of inmates fostering by employ them for providing social service outside the institution. Since it is an external activity, it is considered as a community-based correction. The following is how the correctional social work can reduce the negative effect of inmates fostering institutional-based correction. As widely known, the problem of inmates fostering in correctional institutions became the spotlight of various parties. The public concern on the chaotic fostering comes from the realities as follow. First, there were prison overcrowding in all correctional institutions in Indonesia. This led to fights, narcotics circulations, buying and selling rooms, and bribery. Second, the fostering expended a great amount of state budget. Since there are still many people in society who live below the poverty line, the efforts of the institution to guarantee the inmates' living cost will provoke social criticism. At one hand, the critisicm seems logical. On the other hand, there is an undeniable justification when the country expends budget for inmates' living cost in prison as the consequence of putting them into the institution.Third, it is obvious that institutional-based correction has caused negative and complex effects. Stigmatization, dehumianization, and confinement are inevitable as the effect of correctional activities in the institution. In fact, it all started early when the criminal justice process began in police level. Therefore, correctional institution as the sub-system of criminal justice also bears the same implication with the sub-system preceeds it.

\section{The Juridical Constraints in Applying the Concept of Correctional Social Work in the Act Number 12 Year 1995 towards the Inmates Fostering in Indonesia.}

The following legal norms as the basic regulation of the implementation of inmates fostering describe how the legislation takes part in providing the chance of applying the correctional social work. By referring to various related regulations, we can see how far the concept can be realized. The scope for more civilized inmates fostering is crucial, since the way how a nation responds to the criminal act and its perpetrator reflects its civilization (Nicola Lacey, 2008). Below are the descriptions of various related regulations - both those which provide chance and those which do not - to the application of the concept of conrrectional social work. 
Table 1. The Regulation Pertaining to the Arrangement of Inmates Fostering Formation

\begin{tabular}{|c|c|c|}
\hline \multirow[t]{2}{*}{ No. } & \multicolumn{2}{|c|}{ Regulation } \\
\hline & $\begin{array}{c}\text { The Act Number } 12 \text { Year } 1995 \text { Pertaining to } \\
\text { Correction }\end{array}$ & $\begin{array}{c}\text { The Government Regulation of the } \\
\text { Republic of Indonesia Number } 31 \text { Year } \\
1999 \text { Pertaining to the Inmates Fostering } \\
\text { of Correctional Institution }\end{array}$ \\
\hline 1. & $\begin{array}{l}\text { Article } 1 \text { number } 3 \\
\text { A correctional institution is a place for inmates } \\
\text { fostering }\end{array}$ & $\begin{array}{l}\text { Article } 7 \text { verse (1) } \\
\text { The inmates fostering is implemented } \\
\text { through several stages }\end{array}$ \\
\hline 2. & $\begin{array}{l}\text { Article } 1 \text { number } 7 \\
\text { Inmates refer to those who serve sentences in } \\
\text { correctional institution }\end{array}$ & $\begin{array}{l}\text { Article } 7 \text { verse (2) } \\
\text { The stages of inmates fostering: early stage, } \\
\text { advances stage, final stage }\end{array}$ \\
\hline 3. & $\begin{array}{l}\text { Article } 6 \text { Verse (1) } \\
\text { The inmates fostering is conducted in a } \\
\text { correctional institution }\end{array}$ & $\begin{array}{l}\text { Article 11(1) and (2) } \\
\text { (1) The first and the advanced stages are } \\
\text { conducted in a correctional institution } \\
\text { (2) The final stage is conducted not in a } \\
\text { correctional institution, but in a } \\
\text { correctional center. }\end{array}$ \\
\hline
\end{tabular}

The information for the Table:

1. Article 1 number 3 of the Act Number 12 Year 1995 Pertaining to Correction states that "a correctional institution is a place for inmates fostering".

2. Article 7 (1) of the Government Regulation of the Republic of Indonesia Number 31 Year 1999 Pertaining to the Inmates Fostering of Correctional Institution states that the inmates fostering is implemented through several stages.

3. Article 1 number 3 of the Act Number 12 Year 1995 Pertaining to Correction states that "inmates refer to those who serve sentence in correctional institution".

4. Article 7 (1) of the Government Regulation of the Republic of Indonesia Number 31 Year 1999 Pertaining to the Inmates Fostering of Correctional Institution states that the inmates fostering consists of 3 (three) stages, i.e.:
a. early stage;
b. advanced stage; and
c. final stage.

5. Article 6 (1) of the Act Number 12 Year 1995 Pertaining to Correct states that "The inmates fostering is conducted in a correctional institution and the inmates counselling is conducted in a correctional center".

6. Article 11 of the Government Regulation of the Republic of Indonesia Number 31 Year 1999 Pertaining to the Inmates Fostering of Correctional Institution states that:

(1) The first and the advanced stages are conducted in a correctional institution.

(2) The final stage is conducted not in a correctional institution, but in a correctional center.

Based on the table 1, almost all of the inmates fostering process is conducted in a correctional institution. It means that the regulation is till oriented to the institutional-based correction. This has led to various negative effects. For example, at the institutional level, there are lack of warden in term of both quality and quantity, the lack of budget (Todd R. Clear, George F. Cole, and Michael D. Reisig, 2011), and overcrowding. Moreover, there are also problems among inmates such as narcotics circulations, riots, and violence. The fostering in an institution is initially a reaction and improvement upon inmates fostering in prison (Dwidja Priyatna, 2006), and eventually it generates many problems.

The regulations show that there is hardly any chance for correctional social work. The chance of an inmate participating a social work only provided in the last stage, which is under the responsibility of a correctional center. As stated before, this leads to various negative effects. A monotous fostering in a correctional institution tends to be counterproductive. It is obvious that the concept of inmates fostering regulated in the correctional law, as well as in its derivational law i.e. The Government Regulation of the Republic of Indonesia Number 31 Year 1999 Pertaining to the Inmates Fostering of Correctional Institution only focuses on the internal fostering. There is no enough space for constitutional social work. In various studies and research, it is coconcluded that the internalbased inmates fostering fails to optimally achieve the purposes of correction specifically and purpose of punishment generally. There are a lot of contradiction between the internal fostering and the purposes of punishment.

As generally known, according to the Article 52 (1) of the Bill of Indonesian Criminal Code (RUU KUHP 2019), the purposes of punishment are to:

a. prevent criminal act by enforcing the legal norms for protecting society;

b. socialize the convict by fostering in order to prepare him/her to be morally correct and 
productive;

c. overcome conflict caused by a criminal act, to restore the balance, and to bring security and peace in society; and

d. evoke remorse in perpetrator and free him/her from regret.

The purposes seem too heavy to be burdened with by the internal-based correction. Even though paradoxical, the stages of fostering in correctional institution has always become priority due to the promising cumulation of functions, i.e. as retribution, prevention, handling/restraint, and rehabilitation (Iain Crow, 2001). The concept of institutional-based correction that is opposite to the assumption is far from social realiy. There are many who argue that the inmates fostering in the correctional institution is counterproductive. The refinement process is undeniable reality as the result of fostering inmates in an ineffective institution. On the next level, it is counterproductive and criminogenic. Thus, instead of rehabilitate criminals, the process of internal-based correction tends to incite crimes. It could be labelled as the "college" of criminals.

\section{Conclusion}

Based on the analysis of the problems stated in this research, it is concluded that:

a. The concept of correctional social work can reduce the negative effects of the institutional-based correction such as stigmatization, refinement, and dehumanization.

b. What become the juridical constraints in implementing the concept of correctional social work are the Act Number 12 Year 1995 pertaining to the Inmates Fostering in Indonesia and the Government Regulation of the Republic of Indonesia Number 31 Year 1999 Pertaining to the Inmates Fostering of Correctional Institution. Except the final stages of fostering by correctional center, these regulations do not provide any alternative for external fostering.

According to the above conclusion, the following recommendation can be put into consideration:

a. There is a need of regulation that supports the possibility of correctional social work to reduce the negative effects of the institutional-based correction.

b. Based on the Act Number 12 Year 1995 pertaining to the Inmates Fostering in Indonesia and the Government Regulation of the Republic of Indonesia Number 31 Year 1999 Pertaining to the Inmates Fostering of Correctional Institution, there is no chance for the implementation of correctional social work.

\section{References}

Boonin, David, 2008, The Problem of Punishment, Cambridge University Press, New York

Clear,Todd R., George F. Cole, and Michael D. Reisig, 2011, American Corrections, Ninth Edition, Wadsworth, Cengage Learning, Belmont,USA

Honderich,Ted, 2006, Revised Edition, Punishment The Supposed Justifications Revisited, Pluto Press, Ann Arbor, London

Ibrahim,Johnny, 2005, Teori dan Metodologi Penelitian Hukum Normatif, Bayumedia, Malang

Lacey,Nicola, 2008, The Prisoners' Dilemma: Political Economy And Punishment In Contemporary

Democracies, Cambridge University Press, The Edinburgh Building, Cambridge, UK

Lippman,Matthew Ross, 2010, Contemporary Criminal Law: Concepts, Cases, and Controversies, Sage Publications, Inc., California

Muladi dan Barda Nawawi Arief, 1998, Teori-teori dan Kebijakan Pidana, Alumni, Bandung Priyatna,Dwidja, 2006, Sistem Pelaksanaan Pidana Penjara di Indonesia, PT. Refika Aditama, Bandung

Ross,Alf, 1975,On Guilt, Responsibility and Punishment, University of California Press, California

Satori,Djam'an dan Aan Komariah, 2009, Metodologi Penelitian Kualitatif, Alfabeta, Bandung

Soekanto, Soerjono dan Sri Mamudji, 1995, Penelitian Hukum Normatif Suatu Tinjauan Singkat, Raja Grafindo Persada, Jakarta

Soemitro,Ronny Hanitijo, 1989, Perspektif Sosial dalam Pemahaman Masalah-Masalah Hukum, CV. Agung, Semarang

Sugiyono, 2008, Memahami Penelitian Kualitatif Dilengkapi Contoh Proposal dan Laporan Penelitian, Alfabeta, Bandung

Sunggono,Bambang, 1997, Metodologi Penelitian Hukum, Raja Grafindo Persada, Jakarta

Suriasumantri,Jujun S., 2009, Filsafat Ilmu sebuah Pengantar Populer, Pustaka Sinar Harapan, Jakarta

Suteki, 2008, Rekonstruksi Politik Hukum Tentang Hak Menguasai Negara atas

Sumber Daya Air Berbasis Nilai Keadilan Sosial (Studi Privatisasi Pengelolaan Sumber Daya Air), Dissertation, Doctoral Program of Law,Universitas Diponegoro, Semarang

Suteki, Urgensi Tradisi Penelitian dalam Proses Penelitian Ilmiah, The paper was presented in the national Seminar themed "Research Methodology in Law (Philosophical, normative, and Sosiological-Empirical Perspective)" in the Faculty of Law of Universitas Diponegoro Semarang dated December 16, 2010

Tongat, 2013, Rekonstruksi Pengakuan Dan Penyesalan Pelaku Tindak PidanaAtas Perbuatan Dan 
Kesalahannya Sebagai Faktor Yang Meringankan Pidana Dalam Sistem Pemidanaan Berbasis Keadilan Pancasila, Dissertation, Doctoral Program of Law, Universitas Diponegoro, Semarang, Unpublished

Warassih,Esmi, Penelitian Socio-legal, Dinamika Sejara dan Perkembangannya,

Presented in the Workshop of Updating Research Methodology of Law. Bandung, March 20-21, 2006.

Wignjosoebroto,Soetandyo, 2002, Hukum : Paradigma, Metode, dan Masalahnya, Lembaga Studi dan Advokasi Masyarakat (ELSAM), Jakarta

Wignjosoebroto,Soetandyo. 2007, Disertasi sebuah Pedoman Ringkas tentang Tatacara Penulisannya, Sociology Laboratory of the Faculty of Social and Political Sciences of Universitas Airlangga, Surabaya

Yusriadi, 2009, Tebaran Pemikiran Kritis Hukum dan Masyarakat, Surya Pena Gemilang, Malang

Crow,Iain, 2001, The Treatment And Rehabilitation Of Offenders, Sage Publications, London, Thousand Oaks, New Delhi

The Act Number 12 Year 1995 Pertaining to Correction

The Government Regulation of the Republic of Indonesia Number 31 Year 1999 Pertaining to the Inmates Fostering of Correctional Institution

The Bill of Indonesian Criminal Code until June 25, 2019.

https://ferdfound.wordpress.com/2016/04/25/daftar, accessed on Wednesday, August 7, 2019

Complete Indonesian Dictionary

Tongat, was born in Banjarnegara, January 13th, 1967, completed the undergraduate degree from Faculty of Law at Sudirman University in 1991, graduated master degree from Graduate Program at the Diponogoro University, and pass doctorate degree of Legal Studies Doctoral Program at the Diponegoro University. He Currently working as a Lecturer and Dean at the Faculty of Law, University of Muhammadiyah Malang. The author can be contacted by email: tongat_umm@yahoo.co.id

Ratri, was born in Pasuruan, February 23th,1983.she completed the undergraduate degree from faculty of law University Muhammadiyah of Malang on 2006 and graduated master degree from master of law Padjajaran University in 2012.Now she current working as Lecturer and secretary of program studi at Faculty of Law University Muhammadiyah of Malang. The author can be contacted by email ni_ratry@yahoo.com

Nu'man Aunuh, was born in gresik, november 14th, 1984, completed his undergraduate degree in 2007 at the law faculty, university of muhammadiyah malang and completed his master in 2010 on the same campus, currently active as a lecturer in law faculty at university of muhammadiyah malang and active as chair of the study program. 